became necessary for me to visit the continent I determined to give chloretone a fair test. Not having taken a voyage for five or six years, I practically left myself untreated on the voyage over which lasted some four hours, to test $\mathrm{my}$ seafaring qualities. It was fairly rough but I tried to brave it out, remaining on deck. I was, however, soon completely overcome and before reaching the continental port was very much in the condition of the man who at first was afraid he was going to die, but a little later was afraid he was not going to die. On this occasion when nausea came on I took a dose of chloretone which had no beneficial action, but the test not being a fair one I pass it by. On the return voyage, however, I determined to give the drug every chance. Having one and a half hours' railway journey before joining my boat, I took ten grains of chloretone on beginning this portion of the journey, repeating the dose just before going on board. I remained quietly reclining on deck and took a third dose about an hour after sailing, thus having 30 grains in from two to three hours. The result was absolutely unsatisfactory and during the second balf of the crossing, which this time likewise was fairly rough, I was as ill as I ever was before. Furthermore, the nausea lasted rather longer than usual after landing, but this I put down to mere coincidence. Chloretone in my case proved absolntely useless. A lady doctor of homoepathic tendencies gave me some high-grade petroleum tablets to try. I undertook to do so only in case the chloretone failed and when it was evident that it had I took the petroleum tablets but without avail. I know chloretone is successfal with some individuals, but it failed in my case after a most fair trial.

I am, Sirs, yours faithfully,

South Kensington, Feb. 5th, 1904.

L. Erasmus Ellis.

To the Editors of THE LANCET.

SIRS, - Under the above Mr. Cameron Kidd, in The LANCET of Jan. 30th, p. 334, reports an interesting case of "train sickness" in a little girl successfully treated with chloretone. In 'THE LANCE'T of June 8th, 1895, p. 1434, I drew attention to such cases, recommending sulphonal in varying doses. Common as it is in children, as I pointed out, and trivial as it may seem amongst adults, "railway megrim varies from undue fatigue and inability to sleep the same night to intense headache, sickness, and prostration," and there are many "in whom a railway journey of two hours produces as much dread and misery as a sea passage." At the time of my communication I recollect receiving more than one grateful letter from readers of THE LANCET and since I have often used myself and recommended sulphonal or trional with success. Still, in some cases I have failed and I am especially obliged to Mr. Kidd for his recommendation of chloretone.-I am, Sirs, yours faithfully,

L. Feb:9th, 1904. JohN A. Shaw-Madkenzie, M.D. Lond.

\section{THE REVACCINATION BILL, 1904.}

To the Editors of THE LANCET.

SiRs, - I do not see in the draft of this Bill printed in THE LANCE'I of Feb. 6th any procedure described to secure the revaccination of children in lunatic asylums. I am, Sirs, yours faithfully, W. H. BowES.

Plymouth Borough Asylum, Ivybridge, Devon, Feb. 9th, 1904.

\section{THE INQUEST ON WHITAKER WRIGHT.} To the Editors of THE LANCET.

SiRs,-Mr. D. Biddle in his well-argued letter in THE CANCET of Feb. 6th, p. 394, on the inquest of Whitaker Wright says, "The bluish tint of the body and the fluidity of the blood are neither separately nor together distinctive of poisoning by prussic acid." As to the fluidity of the blood I cannot speak positively, but I think that if the body is seen soon after death the blue colour may be looked upon as pathognomonic of poisoning by hydrocyanic acid.

Some years ago I was first impressed with this fact by a melancholy case of poisoning by prussic acid which came under my observation. The subject was a handsome, fairskinned, young man who, in a tit of temporary insanity, drank an ounce of hydrocyanic acid. I saw him a few minutes after he had $s$ wallowed the fatal draught lying dead on his bed and the empty bottle, which had evidently contained the acid, was on a chair by the bedside. As regards the appearance of the body, the first thing that attracted my attention was the brilliant violet colour which the skin presented. Several hours afterwards when I again saw the body the violet colour had considerably faded. The intensity of the colour in this case may have been owing to the large quantity of poison taken. Dr. Taylor, in his book on Poisons, mentions a violet colour as one of the appearances met with after death from poisoning by hydrocyanic acid. I am, Sirs, yours faithfully,

William O'Neicl, M.D. Aberd., M.R.C.P. Lond., \&c. Lincoln, Feb. 6th, 1904.

\section{THE DESTRUCTION OF TUBERCULOUS SPUTA.}

To the Editors of THW LANOET.

SIRs, - I notice in a paper by Dr. C. T. Williams that he advises as a convenient method of destroying the expectoration of tuberculous patients mixing it with sawdust and burning it. For some years I have advocated the following plan which appears to me a more complete system. A small cardboard box is half filled with sawdust which is damped with paraffin. Into this the patient expectorates and at the end of the day it is easily burnt. Even in the summer when there may be no fire, a match will be sufficient to cause its total destruction. Most householders have a superfluity of such boxes and are pleased to find a use for them. If a cup is used or a bottle to carry about it is quite easy to have a lining of greased paper which can be lifted out with its contents each night and burnt.

I am, Sirs, yours faithfully,

J. LIONEL STRETTON,

Feb. 2nd, 1904. Senior Surgeon, Children's Hospital.

\section{MEDICAL ACTS AMENDMENT BILL. To the Editors of THE LANowT.}

SiRs, - I am glad to learn from THE LANCET of Jan. 30th, p. 339, that Clause 34 of the Medical Acts Amendment Bill has met with adverse criticism at the meeting of the Cardiff division of the British Medical Association. My surprise is that any division has tolerated it. In my opinion it is quite unnecessary to protect the profession from nnqualified practitioners and would certainly be very detrimental to the interests of the general practitioner. Few of us in such conditions would care to employ an assistant and an additional hardship would be thrown on those who are obliged to. In addition to the increased facilities given to an unscrupulous assistant to pretend to partnership there is the obvious harm likely to arise to a practice from the open advertisement in connexion with it of men who, later on, may become notorious black sheep. Considering the complaints so often made in the medical press of the class of practitioner too frequently foisted on us as assistants, and that two months is far too short a time for the principal to find out the character of his assistant, the exemption suggested is practically of little use.

For my own part, if this clause is retained I would rather see the whole Bill-which in many points is an excellent one-lost, so detrimental do I consider the conditions it lays down to the best interests of the general practitioner. I am, Sirs, yours faithfully, MAJOR GREENWOOD, M.D. Brux., LL.B.,

Hackney-road, N.E., Feb. 4th, $1904 . \quad$ Barrister-at-law.

\section{THE TEACHING OF BIOLOGY. \\ To the Editors of THE LANCET.}

SIRs, - In July last a committee appointed by the Royal Colleges of Physicians of London and of Surgeons of England to consider what alterations, if any, were desiraple in regard to the conduct of the First Examination of the Conjoint Board issued a report containing certain suggestions which deal, inter alia, with the teaching of biology. The report has been adopted by the Colleges and in pursuance of its recommendations an attempt is now being made by the committee to elicit the opinions of teachers in the metropolitan and provincial schools on the following points :-

1. What alterations, if any, are desirable in the synopsis for elementary biology? 